\title{
INTERLUDE IN AUSTRIA
}

\author{
SAlzburg, 1953
}

\author{
By A. M. V. Boyle
}

After the technical meeting of the International Union for the Protection of Nature, many of the participants and their wives were able to take part in the excursions arranged by the local organizing committee. On the afternoon of 18th September, we visited the Salzkammergut, a district east of Salzburg which could be compared to our lake district. Here is a network of beautiful lakes with steep wooded hills and sheer cliffs dropping to the blue water. At the Fuschl See, our first stop, Ribbentrop and Ciano had had many meetings during the war in the castle hotel overlooking the lake. The near-by pastures were covered with pale mauve meadow saffron, and beside the path we saw Gentiana germanica and a fine group of the shaggy ink cap fungus (Coprinus comatus). We went on to the Wolfgangsee and Mondsee, returning to Salzburg in the evening. Later my husband and I spent a few days on the shore of the Wolfgangsee and were able to explore at leisure.

A protected area of 500 metres' width has been established round each of these lakes to preserve the countryside from the depredations of the many visitors in the holiday seasons. Litter seems to be a problem, judging by the paper and tins lying about near the lakeside paths. Notices prohibit making fires, shooting, allowing dogs to wander unleashed and uprooting plants. One notice points out that bathing costumes are all very well on the shore, but are out of place on the roads and in the villages.

The woods we saw were mainly beech and pine with some sycamore, white beam, ash and rowan. The attractive small Cyclamen europaeum was quite common in the shade under the trees. Apart from a great many jays, there were surprisingly few birds. Several flocks of tits were moving among the trees along the shore, among them at least one crested tit, and there were tree creepers and nuthatches in the woods. We saw a white-backed woodpecker (Dryobates leuconotus) and a hen pied flycatcher.

The lake itself had little vegetation in it, although there seemed to be a good many fish, and the only water birds we saw were one mallard and a party of great-crested grebes, two adults and two young birds. Paths providing pleasant walks in the neighbourhood have been marked with numbers 
painted on trees and rocks. This seemed a little too painstaking when it came to a morning stroll by the lake with seats at strategic intervals. However, we were glad to take advantage of route No. 20, which guided us on a splendid walk up the Scharfberg. This is the highest point in the immediate neighbourhood and rises to 5,800 feet above sea level, the lake being about 1,800 feet. On this walk we climbed steeply up through the beech and pine woods, passing all sorts of interesting plants on the more open hillside, but able to recognize only a very few. There were bushes of deadly nightshade, wild raspberries and strawberries, various campanulas and three kinds of gentian in flower, including, on the damp hillside, Gentiana asclepiadea. Above the trees on the drier hillside was Carlina acaulis, a bristly sort of thistle flat on the ground with a flower resembling an "everlasting". The last 1,000 feet above the trees was a struggle for our untrained muscles. Small tortoiseshell butterflies were common, visiting the late summer flowers.

The sharp mountain is well named, for on the north and east sides there is a sheer drop of at least 2,000 feet to the fields and woods which slope down to the Mondsee and Attersee. All around below you are blue lakes; beyond to the east the bare rock faces of the Totes Gebirge, and piled up round the south horizon all manner of oddly shaped mountains and the snowcovered peaks and glaciers of the Dachstein. Rather surprisingly on this sharp summit there is a large hotel, connected by funicular to the town of St. Wolfgang. Alpine choughs seem to have found an ecological niche based on the hotel, and there were many scavenging happily on the kitchen refuse. They are tame and attractive birds with their glossy black plumage, short yellow bills and orange-red legs. They perform delightful aerobatics and utter curious high-pitched cries.

Returning now to the organized tours - on the morning of 19th we left Salzburg early and drove south to the Pinzgau region, turning westwards up the Salzach river. To the south of this broad valley stands the great range of the Hohe Tauern from which steep torrents run down to add their milky glacial water to the main stream. This is a cattle and horse rearing district, the cows being of the special Pinzgauer breed, brown on the flanks and white on the back and underside. This colouring makes them show up clearly on the hillsides, whether viewed from above or below. The horses are a fine and sturdy breed. Throughout the summer most of the cows are grazing on the upper slopes and are brought down when cold weather sets in. The lower pastures are meanwhile cut several times and the 
hay dried on small tripods in the fields for winter feed, which is always scarce. Each field has its stout wooden cabin for storing the hay.

At the head of the valley is Krimml, with its famous waterfall, said to be the highest in Europe. It has a drop of nearly 1,500 feet in three falls. The cauldron of swirling spray at the foot of the lower fall is a magnificent sight. Some years ago a plan was set afoot to divert the water from above the falls for a hydroelectric scheme in the Tyrol. All the Austrian societies interested in nature protection fought this project and the International Union intervened to such good purpose that the scheme is now in abeyance.

After spending the night at Zell am See we drove up the Grossglocknerstrasse. This remarkable road follows the valley up the Fuscher Tal to Ferleiten, then climbs in a series of tight hairpin bends to the first pass at about 7,500 feet. The lower slopes are wooded with spruce and larch; above at about 6,000 feet there grows an attractive dwarf pine. There are wonderful views of bare rock, glacier and snowy peak. At the first pass we were fortunate enough to see five griffon vultures circling high overhead. Further on, one branch of the road ends at the Franz Josefs Hohe, where a large hotel has been built overlooking the grey sheet of the Pasterzenkees glacier. Beyond rise the high peaks, with the Grossglockner itself leading them all at 12,400 feet.

At this hotel, too, we noticed that the alpine choughs were very much at home. Here also were ravens and, on the hillside above, a flock of snow finches. There were many interesting plants, all low-growing, including dwarf willows, several gentians, a geum and the persevering cushion plant, which takes many years to grow from a single base.

Although it is wonderful to be able to reach places which would normally be accessible only to the mountaineer, one realizes how easy it would be to overdo the mountain roads, funiculars and cable railways. The big tourist hotels which are thus enabled to exist in the most unlikely places are no doubt attractive to many visitors, but can hardly be said to improve the natural scene. 